\title{
A Retrospective Analysis: 1996 Atlanta Summer Olympics and Lessons for Future Olympic Cities
}

\author{
Tuna Batuhan
}

Keywords:

Mega-event planning, Olympics,

Atlanta,

Planning Practice

\author{
Article History: \\ Submitted:06.12.2019 \\ Accepted: 24.04 .2020
}

\begin{abstract}
This paper examines the rationale of the 1996 Summer Olympics bid of Atlanta and provides a retrospective analysis of the short- and long-term impacts of the Olympic Games. Olympics provided a means to facilitate the primacy of downtown Atlanta and this new strategy was partially successful mainly because of other external factors. The elites of downtown Atlanta seized the opportunity presented by a potential Olympic hosting in Atlanta to make promises and implement a vision that revitalizes certain downtown areas. Atlanta's Olympic strategy gave positive results in the short-run, however did not help to increase the primacy of downtown Atlanta in the long term due to short-term focused strategies, prioritizing regional issues and shifting focus of business elites to regional growth. Atlanta's Olympic planning practice mostly benefited the business interests while the desires and needs of the residents mostly disregarded, mainly because of the privately-lead planning initiatives. Atlanta Olympic planning practice showed that privatization of the Olympic planning results in limited effects in urban transformation. This paper concludes that the Olympics is not a "one-fits-all approach" for host cities, thus the outcomes differ from city to city mainly because of the different objectives, politics, and culture of each city.
\end{abstract}

Doi: https://doi.org/10.31822/jomat.656291

\section{Introduction}

\section{A Brief History of the Olympic Games}

The largest exceptional public events (ECMT, 2002) that are defined as 'mega' includes the Summer Olympic Games, Expos, World Cups, and Commonwealth Games, which attract millions of visitors and also justify large-scale infrastructure development (Roche, 2002). Mega-events have the potential to be the catalyst for host cities to apply their planning strategies in a more focused environment, and they can result in remarkable changes in infrastructure, urban form, and city image (Essex and Chalkley, 1998; Essex and Chalkley, 2003. According to Essex and Chalkley (1998), the Olympic Games offer "the justification for related developments to be 'fast-tracked' through accelerated planning, design and construction." (p. 201). Mega-events are "the best stage upon which a city can make the claim to global status" (Short, 2004, p.24).

1976 Montreal Games and 1984 Los Angeles Summer Olympic Games are two mile stones for the Olympic movement in terms of the financial concerns. 1976 Montreal Games concluded with a debt of $\$ 2.8$ billion, and cities hesitated at hosting the 1984 Olympics. Two years before the 1976 Olympics, the host city for the 1980 Olympics had already been selected. Los Angeles and Moscow were the only two cities to bid for the 1980 Summer Olympics, and Moscow was selected over Los Angeles as the host city in 1974. After the financial problems of 1976 and 1980 Games, only two cities expressed their interest for hosting the 1984 Olympics: Tehran and Los Angeles. When Tehran decided to drop out, Los Angeles became the only bidding city and was awarded to host the 1984 Summer Olympic Games by default. Two consecutive Olympic Games were boycotted; USled boycott of the 1980 Olympics prompted the Soviet-led boycott of the 1984 Olympics. 1984 Los Angeles Olympic bid was privately-initiated by a group of business leaders (Burbank et al., 2002). The City of Los Angeles refused to sign financial responsibility contract with IOC (Rule 4) and IOC had no other option rather than waiving this rule for 1984 Olympics (IOC, 1978; 1979). This could explain "the absence of significant public sector financial support in Los Angeles, and, perhaps, the private financial success the 1984 Games are thought to have enjoyed." (Baade and Matheson, 2002, p. 32) The success of Los Angeles Games and 
the profit that is generated increased the interest of other cities to host the Games. The 1984 Los Angeles Games were staged only six years earlier at the time of 1996 Olympic host city selection process. Atlanta tried to distinguish itself from Los Angeles and emphasized the city's advantages.

Especially after the 1984 Los Angeles Games, the economic value of the Olympics has increased. The Los Angeles approach to the bidding process changed "the Olympic Games financial model for less public and more private financing" (Zimbalist 2011, p. 120), and showed that the Games could be profitable. The Games generated positive publicity for the city and its tourist industry with a minimum amount of tax money. Therefore, hosting the Games became more popular and got more attention from city leaders all around the world (Burbank et al. 2001). The image of a successful Olympics and $\$ 223$ million profit of Los Angeles Olympics increased the number of competing cities for the following Summer Olympic Games. As seen in Table 1, Olympic Games has been growing in many aspects since the 1984 Los Angeles Olympics (ACOG 1994; ATHOC 2004; 2005, CMB 1986; Currie 2007; Greater London Authority 2011; OASA 2009; ODA 2009, ORTA 2001; IOC Website; IOC 2006).

The Olympic Games are one of a kind opportunity for any city to attract global attention and become the center of the globe for three-week period. This is one of the main motivations for cities to compete for hosting the Games. The Olympics could also serve as a catalyst to solve the aged urban

Table 1. The Growth of the Summer Olympic Games

\begin{tabular}{|c|c|c|c|c|c|}
\hline Host City & 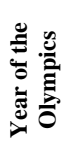 & 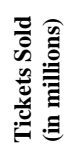 & 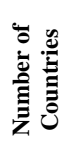 & 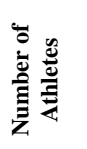 & 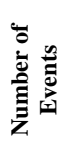 \\
\hline $\begin{array}{l}\text { Los Angeles, } \\
\text { USA }\end{array}$ & 1984 & 5.7 & 140 & 6.829 & 221 \\
\hline $\begin{array}{l}\text { Seoul, } \\
\text { Korea }\end{array}$ & 1988 & 3.3 & 160 & 8.391 & 237 \\
\hline $\begin{array}{l}\text { Barcelona, } \\
\text { Spain }\end{array}$ & 1992 & 3 & 169 & 9.356 & 257 \\
\hline $\begin{array}{l}\text { Atlanta, } \\
\text { USA }\end{array}$ & 1996 & 8.4 & 197 & 10.318 & 271 \\
\hline $\begin{array}{l}\text { Sydney, } \\
\text { Australia }\end{array}$ & 2000 & 6.7 & 199 & 10.651 & 300 \\
\hline $\begin{array}{l}\text { Athens, } \\
\text { Greece }\end{array}$ & 2004 & 3.6 & 201 & 10.625 & 301 \\
\hline $\begin{array}{l}\text { Beijing, } \\
\text { China }\end{array}$ & 2008 & 6.5 & 204 & 10.942 & 302 \\
\hline $\begin{array}{l}\text { London, } \\
\text { UK }\end{array}$ & 2012 & 8.2 & 204 & 10.500 & 302 \\
\hline $\begin{array}{l}\text { Rio De } \\
\text { Janeiro, } \\
\text { Brazil } \\
\end{array}$ & 2016 & 6.5 & 205 & 11.384 & 306 \\
\hline
\end{tabular}

Source: Compiled by author. Adapted from ACOG 1994; ATHOC 2004; 2005, CMB 1986; Currie 2007; Greater London Authority 2011; OASA 2009; ODA 2009, ORTA 2001; IOC Website; IOC 2006 problems, and could "provide a unique opportunity for politicians and industry to move hidden agendas such as the improvement of infrastructure for sport, housing, communication, traffic and other sectors" (Preuss, 2004, p. 1).

\section{Literature Review}

The Logic Behind The Olympic Bid of Atlanta

Cities' interest in global networking and the increasing competition among cities are merged into economic strategies and hosting a mega-event like the Summer Olympic Games is seen as a convenient vehicle to achieve the economic goals of a city such as image creation, tourism, and business investments. The difficulties that the city government and the business leaders face within the broader political and economic environment and within the changing forces in international economy required American cities to play an entrepreneurial role; thus, hosting a mega-event like the Olympic Games became a major way to help any city achieve local economic goals (Burbank et al., 2001; Heying et al., 2007). In contemporary American cities, staging the Olympic Games is not simply an international sporting event but a tool for implementing the vision of a world-class city by providing opportunity for growth (Burbank et al., 2001; Preuss, 2004; Short, 2018).

In this sense, Atlanta's bid for hosting the Olympic Games can be understood as the product of an active growth coalition that already existed in Atlanta. The Olympic regime was created in the form of influential individuals getting involved with the bidding and planning for the Olympics in order to make their vision the local policy agenda. For Atlanta, the vision and the central motivation among growth elites was to show that Atlanta was a "world-class" city capable of hosting the Olympic Games. The city leaders and the business elites used tourism and convention to promote the city's economic development and attract tourists and business investments. In order to justify local development in Atlanta, public policy strategies promoted tourism, and the Olympic Games provided that promotional means to reach a broader population (Burbank et al., 2002). For Atlanta, the Olympic bid was not just about hosting a major sporting event, but about transforming the city into a world-stage player, which has been part of the long-running agenda of the downtown elites. The Olympic Games provided an opportunity for downtown business elites to overcome the loss of interest in downtown Atlanta and to increase their power in manipulating and shaping policy 
decisions. The business elites' strategy was using the Olympics to facilitate the primacy of downtown Atlanta (French and Disher, 1997).

Downtown Atlanta business elites has functioned as a powerful figure to manipulate and shape the planning decisions in downtown Atlanta since 1950s in order to increase their business interests. Downtown Atlanta policy was driven by the governing coalition, consisting of the business elites, elected mayors, and black electoral power in order to increase the primacy of downtown Atlanta and further their objectives in the phase of suburbanization/decentralization. During Hartsfield's and Allen's mayoralty, with the strong support of downtown business elites and black votes, Atlanta's governing coalition was successful implementing their policy agenda by using every policy tool, including transportation plans, sports and convention facilities, urban renewal, and other federal laws. Atlanta achieved continues growth and by the end of Allen's mayoralty (1970) the city completed its transformation from a regional capital to a national city (Allen, 1971; Stone, 1976).

1970s was also the time when the transition in regime started with the election of Massell and Jackson as mayors. The regime dynamics began to change with blacks' stronger presence in Atlanta politics, but the power of business elites on governing coalition have not weakened. In late 1980s, Atlanta looked completely different than it was in the previous decades; the blacks were the voting majority since 1970 s; the city lost population and its population share declined on the metropolitan level. The city was not able to keep pace with the changing local and national dynamics. The city experienced "white flight" starting in the 1960s. Improved transportation technology, extended highway network throughout the nation, and national policies supporting home ownership resulted in migration of middle class and live further from their workplace. In addition to these national forces and policies, fear of crime, concerns about city schools, and higher share of property taxes for services in downtown influenced the location decisions of white middle class (Banfield, 1965; Holmes (1977; Murphy, 1997).

Despite these changing dynamics, downtown Atlanta business elites believed that downtown Atlanta would keep its primacy in the region by investing on city's unique strengths, including the infrastructural facilities such as the airport, rapidrail system, and the freeway network; strong convention and tourism industry; concentration of strong institutions and industries; and strong economy and business community. As a result, Atlanta business leaders turned to market based solutions, such as tourism and convention, in order to generate profit and increase the reputation of the city in an era where the manufacturing is declining and the competition with the surrounding suburbs for office space tenants and residents has intensified. In other words, the focus of the governing elites shifted to planning for visitors, not for residents. The future of downtown Atlanta is imagined as a place for consumption, not for production (Andranovich et al. 2001; Keating, 2001; Rutheiser 1996).

Although some elements of the regime have changed over time, the regime sustained its stability and the business elites committed on the "regressive agenda" of economic growth. In this sense, the idea of hosting major conventions and events became a new strategy. The rewards of these efforts was hosting some major events later, including the 1988 Democratic National Convention, 1994 NFL Super Bowls, and finally the 1996 Summer Olympic Games(Andranovich et al. 2001; Heying et al. 2007).

The Olympic Bidding and Preparation Process of Atlanta The Olympic journey for Atlanta started on February 8, 1987, when William Porter "Billy" Payne, a real estate lawyer and former football player at the University of Georgia, dreamed of Atlanta hosting a summer Olympic and began campaigns to win the right to host the 1996 Summer Olympic Games. In Atlanta, no organization was in place to initiate an Olympic bid. Thus, Billy Payne, as Atlanta's “Olympic entrepreneur" (Burbank et al., 2002), formed the bidding committee of Atlanta and formed the Georgia Amateur Athletic Foundation (GAAF), a non-profit corporation in 1987 for the USOC's endorsement for the 1996 Olympics. Payne's Olympic dream became more possible to achieve after he got the support from mayor Andrew Young and other business leaders, especially Roberto Goizueta of Coca-Cola. Later, mayor Young took the first official step by sending a letter to the United States Olympic Committee (USOC) in August 1987, expressing the City of Atlanta's interest in being the US nominee for the 1996 Summer Olympic Games (Newman, 1999). In September 1987, GAAF members submitted the formal bid materials in person to the USOC headquarters in Colorado Springs, Colorado (ACOG, 1996; ACOG, 1997). GAAF members met the sport federation leaders and discussed the aspects of Atlanta's bid. The bid described 
Atlanta's strengths as follows: a world- class airport; existing venues and facilities; new construction plans for sports venues; more than 60,000 existing hotel rooms; the MARTA system; experience in handling large masses of people because of the city's large convention industry; and private funding through corporate sponsors, television rights, and ticket sales. (ACOG, 1997, p. 7)

On April 29, 1988, USOC selected Atlanta as the US nominee to host the 1996 Summer Olympics. Atlanta won 65-42 over Minneapolis-St Paul (AJC, April 30, 1988). After winning the designation as the US nominee, a new organization, the Atlanta Organizing Committee (AOC), was created by Billy Payne and his friends for the international Olympic campaign. In May 1988, international competition started for Atlanta. Atlanta competed against five other cities: Athens, Greece; Toronto, Canada; Manchester, England; Melbourne, Australia; and Belgrade, Yugoslavia to become the host city for the 1996 Olympics. The modern Olympic Games began in 1896 in Athens and the 1996 Olympics was the 100th anniversary of the Games. Thus, it was assumed, at least by Greece, that Athens has the biggest chance to win the bid and host the Centennial Olympic Games (Hutton, 2001; Payne, 1997).

Atlanta's Olympic bid proposed to spend about $\$ 1.2$ billion in private funds to hold the Games, and expected to generate about $\$ 1.4$ billion in revenues from television broadcast rights, commercial sponsorships, tickets, and other promotions (Weisman, 1990).

On September 18, 1990 IOC awarded the 1996 Olympics to Atlanta at the 96th Session of IOC in Tokyo, Japan. An exuberant crowd in Underground Atlanta celebrated the announcement that Atlanta will host the 1996 Olympic Games. Atlanta used technology, an image of enthusiasm along with the strong support from Atlantans, and the organization skills to be selected over Athens by a 51-35 vote to host the Games after five rounds of voting (Table 2 shows the five- round sequence of IOC votes). Atlanta's selection as the 1996 Olympic host city was surprising, even for Atlanta bidding committee. Atlanta was "the best city of the rest" to prepare itself for the 1996 Olympic Games on time with its concepts for transport - especially the air connection to the world with one of the leading airports in the world-, infrastructural facilities, 65,000 hotel rooms, existing sport facilities, and communication systems (IOC, 2009).
Table 2. IOC Voting for the 1996 Summer Olympic Games Candidate

City

\begin{tabular}{|c|c|c|c|c|c|}
\hline & $\begin{array}{l}\bar{\Xi} \\
\widetilde{\Xi}\end{array}$ & 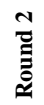 & 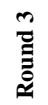 & $\begin{array}{l}\underset{\Xi}{\Xi} \\
\stackrel{\Xi}{\Xi}\end{array}$ & 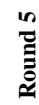 \\
\hline Atlanta & 19 & 20 & 26 & 34 & 51 \\
\hline Athens & 23 & 23 & 26 & 30 & 35 \\
\hline Toronto & 14 & 17 & 18 & 22 & - \\
\hline Melbourne & 12 & 21 & 16 & - & - \\
\hline Manchester & 11 & 5 & - & - & - \\
\hline Belgrade & 7 & - & - & - & - \\
\hline
\end{tabular}

The business elites heavily engaged in Olympic bidding and preparation processes. Atlanta's Olympic bidding committees consisted of influential business leaders; especially Goizueta of Coca-Cola was the "behind the scene" figure for Atlanta's Olympic bid. In a sense, the bidding committee was another ad hoc form of the governing regime in Atlanta. With extensive lobbying effort, enthusiasm, and organization skills, Atlanta convinced the IOC members and the 1996 Olympics was awarded to Atlanta. Atlanta came forward with its sports facilities already in place, transportation network, and strong convention business. This proves the success of business elites' vision in a sense that investing on Atlanta's unique strengths and turning to marketbased solutions would help the city to keep its primacy in order to generate profit and increase the reputation of the city (Keating, 2001).

From its bidding period to the Olympic staging, Atlanta Committee for the Olympic Games (ACOG)'s strategy was to meet the Olympic requirement at the minimum level by limiting its attention "inside the fence", increase the profit, and implement the long-dated agenda of putting Atlanta on the international map. Corporation for Olympic Development in Atlanta (CODA), which was intended to plan and coordinate redevelopment projects "outside the fence", was not successful to increase the community benefits of the Olympics. Besides the limited funds, the major problem with the unsuccessful CODA venture was that the downtown business elites did not genuinely support CODA. ACOG was representing the business elites' interests while CODA was trying to increase the benefits of the Games for Atlantans ((Rutheiser 1996, French and Disher, 1997; Hoffman, 2003).

\section{Study Design and Methodology}

Case study methodology was employed for this research (Mossberger and Stoker, 2001) and Atlanta was selected as the single case. This single- 
case study investigation engages a wide literature on regime theory, mega-event planning, and urban planning; archival data; and in-depth interviews with area urban planning experts, business leaders, and other interested parties in order to examine the propositions stated above. The study covered the time period from 1950 s to 2000 s to set the boundaries of the case.

This qualitative case study investigation used multiple sources, including public agency documents at different levels; interviews with key decision makers; academic articles and books researching urban planning, regime theory, and mega-event planning; newspaper articles; and other online documents. Both primary and secondary data are reviewed: the official documents and reports from various governmental and non-governmental organizations (Public and private memos, local government policy statements, Olympic host city report, master plans, official websites), previous academic studies on mega-event planning, regime theory, planning policy, and press releases and media reports from local and national newspapers. The resulting information created a triangulation at the data collection level to ensure cohesive research findings.

\section{Results: The Legacy of 1996 Atlanta Olympics}

Atlanta's Olympic strategy gave positive results in the short-run, however did not help to increase the primacy of downtown Atlanta in the long term due to short-term focused strategies selected by downtown business elites as well as prioritizing regional issues and shifting focus of business elites to regional growth. The regime in Atlanta was different than what it was in 1950s or 1970s. Economic, social, demographic, and political changes resulted in changes on governing coalition and the elites' focus have shifted to regional issues rather than concentrating on downtown Atlanta.

First of all, the Olympics created some positive tangible legacies, most notably the Centennial Olympic Park; the new Olympic Stadium; new concourse and a central atrium for the HartsfieldJackson Atlanta International Airport; and new facilities for Colleges and Universities in or near downtown Atlanta. In addition to these tangible benefits, the Olympic Games was also a catalyst for some other physical improvements, such as the $\$ 16$ million ITS system; $\$ 100$ million Empowerment Zone designation to enhance housing, childcare, and job training in a nine square mile area in downtown Atlanta; and the $\$ 14$ million federal grant for MARTA to purchase natural gas buses which will be showcased during the summer of 1996. The Olympic Games also contributed to the growth of convention business. Additionally, Atlanta hosted more major sports events after the Olympics. Lastly, the new housing units in downtown Atlanta stand as one of the tangible legacies of the Olympics.

In terms of intangible legacies, one of the goals of the Atlanta Olympic organizers was to create a world city image. This goal was achieved with the Olympic hosting and Atlanta was finally on the map as an international city. The Games also served as an excuse to guarantee to complete the infrastructure on time. The tight deadlines of the Games forced the agencies to cooperate and do much work in a short time and the Olympics helped to make the process faster. Additionally, as another intangible legacy, the Olympic transportation planning experience changed the perception on transit and proved the capacity of MARTA system, the airport, and the convenient location of Atlanta.

In regards to negative legacies, the Games had negative social impacts on low-income residents, intensified social problems and deepen existing divides among residents. The Olympic Games did not increase the quality of life for the residents of Atlanta, especially the poor. Atlanta focused more on "Olympics-as-sport" side and the needs of communities are disregarded. Atlanta's Olympic primary effort aimed to meet the IOC requirements in a most efficient way from Games organization to architecture with limited infrastructure investment. Atlanta staged the Olympic mostly with temporary infrastructural improvements and not necessarily targeting for a legacy after the Games. Atlanta used its key strengths, such as convention sport facilities and transit system to be awarded to host the Olympics, in contrast to other host cities which used Olympics to improve their urban infrastructure and create a legacy. In one sense, Atlanta was ready to manage Olympic-sized events, but the privately-led approach and profitmaximization idea limited the city's capacity to prepare for the Games with a comprehensive planning approach and handle the Games without major problems.

\section{Overall Assessment of 1996 Atlanta Olympics}

The 1996 Olympics served as a catalyst for physical development in downtown Atlanta. The Atlanta Olympics raised the global profile of Atlanta, improved the city's attractiveness for new businesses to locate, increased growth in service industry - especially in tourism and convention sectors, created a sense of pride for Atlantans, and 
improved the physical environment with some tangible legacies, such as the new sports facilities, the Centennial Olympic Park, beautification of the city, new dorms for Georgia Tech and Georgia State Universities, and new housing options in downtown. Olympics and post-Olympics construction projects have made profound changes in and around the edge of the CBD.

The Olympic strategy of downtown Atlanta business elites was partially successful. The Olympic organizers used the key strengths of Atlanta such as the convention facilities, rapid-rail system, the airport to get the Olympics, but they failed to address political, economic, and social problems because of the short-term vision and lack of planning during the Olympic preparation process. French and Disher (1997) examined the lessons from Atlanta Olympics for prospective host cities. In this study, four main expected benefits of large scale events for the host cities are listed: creating a physical legacy, short-term economic stimulus, marketing and tourism opportunities, and sufficient urban redevelopment. The study concluded that the first three benefits are achieved; however the hardest benefit to obtain from the event - significant urban redevelopment remained as a dream for Atlanta. According to this study, the main problems that bounded Atlanta from obtaining this benefit were dependence on private funding sources and divided management body.

The Olympics were a significant attempt for downtown business elites to keep the downtown area vibrant, attractive, and lively. As a result of the Olympic hosting in 1996, Atlanta finally received the "international city" title and the original business development agenda largely accomplished for downtown business elites. As a reflection of the existing regime in Atlanta, the lack of public involvement and public funding also meant that implementing comprehensive, longterm oriented, and integrated planning was limited in Atlanta Olympic planning process. The legacy of Olympics in Atlanta was not long-lasting and hard to be recognized. Atlanta's bid strategy was not grounded in a specified long-term plan that includes venue planning, funding sources, citizen participation, and community involvement. As a result, the Olympics was relatively unsuccessful and did not create positive lasting legacies.

\section{Discussion and Results:}

\section{Lessons for Future Olympic Cities}

The sole purpose of the Atlanta's Olympic bid was to increase the city image and attract businesses.
Even though it was expected that the city and its residents would benefit from the Olympics, it was not part of the business elites' agenda. Atlanta Olympics served only narrow purposes and the local politics and power structure determined the outcome of the Atlanta Olympics. Despite neighborhood resistance and opposition, business elites' redevelopment projects were implemented including the Centennial Olympic Park and the new Stadium, which proves the power of business elites in manipulating and shaping policy agendas. Olympics served as a catalyst for economic revitalization around the Centennial Olympic Park. New housing units, new hotels, and new retail spaces are added to the area after the Olympics. Overall, 1996 Olympics renewed the interest in the future of downtown Atlanta: the city and the business elites benefited from Olympic legacies, however the Olympics failed to address socio-economic problems and the benefit to the overall community was limited.

Atlanta focused more on "Olympics-as-sport" side and the needs of communities are disregarded. Atlanta's Olympic primary effort aimed to meet the IOC requirements in a most efficient way from Games organization to architecture with limited infrastructure investment. Ginger Watkins, ACOG's managing director of corporate services, sees the Olympics as an image-enhancing opportunity for Atlanta and he describes this effort as follows: "despite the huge effort ACOG undertakes through the "Look of the Games" program, what we are really doing is "decorating" Olympic venues and transportation corridors." (Watkins, 1993).

Olympic Games marked the last phase of civic and downtown orientation of business elites. From the business elites' perspective, the Olympics partially delivered the expected benefits, such as revitalizing specific downtown areas, increasing the global recognition of Atlanta, and attracting more businesses and residents to downtown Atlanta. These effects were positive for a shorttime period right after the Olympics, but these benefits were not long-lasting and did not help to facilitate the primacy of downtown Atlanta for the long-term because of other internal and external factors. After the Olympics, the business elites' focus shifted towards regional issues and downtown Atlanta lost its priority to be an attractive location for business interest over growing surrounding suburbs. Although city employment increased in the post-Olympic period, the city's share in the region declined. Atlanta has 
also been promoted as a site for regional offices. This goal was accomplished with the Olympics, but the changing dynamics prevented Atlanta to keep its primacy as the regional economic center. In other words, regional growth surpassed downtown growth and the regime lost its interest to implement policy changes in downtown Atlanta as a result of changes over time with new actors gaining more power in city politics. With the changing demographics, immigrants, multiethnic groups, and labor movements are now part of the regime analysis. In regards to Olympic planning practice, Atlanta can be considered as an outlier.

Atlanta was the second Olympic host city after Los Angeles, which heavily relied on private funding for Olympic planning. The absence of government backing created a planning environment where increasing profit was the main target, not creating a legacy of the Olympics. Eventually, after the Atlanta Olympics, one lesson IOC learned was to require government involvement on Olympic planning. Richard Pound, Vice President of IOC at that time, delivered a speech at the Ambassador's Lecture Series in Washington D.C. on May 16, 1994 and said, "We [IOC] will never award the Games in future to a city, in the United States or elsewhere, which has no significant public sector commitment, either in the form of financial contribution or, at the very least, in the form of a guarantee to meet the necessary costs of organizing the Games" (Pound, 1994).

Additionally, the Olympic bidding process in today's world is a lot more competitive, more complex, and has string rules. In a sense, Atlanta Olympics was a bitter experience for IOC and one period was closed with in Olympic history with the 1996 Atlanta Olympics. As one of the ACOG member stated, "now, the technical requirements for a bid are huge. It is too comprehensive. All we did was identifying locations for the venues. It would be interesting to see how much of it we changed. We were going to have 5 venues in Stone Mountains, but we ended up 2. It is a whole different time now. The contract we made was may be 10 pages, it is now about a 100 pages. When Moscow won in 1980, their contract was a onepage document" (ACOG Member 1).

Another important lesson for IOC was to include legacy aspects to the Olympic bidding process. Atlanta staged the Olympics mostly with temporary infrastructural improvements and not necessarily targeting for a legacy after the Games. Atlanta used its key strengths, such as convention sport facilities and transit system to be awarded to host the Olympics, in contrast to other host cities which used Olympics to improve their urban infrastructure and create a legacy. In one sense, Atlanta was ready to manage Olympic-sized events, but the privately-led approach and profitmaximization idea limited the city's capacity to prepare for the Games with a comprehensive planning approach and handle the Games without major problems. This study intended to contribute to the body of literature in urban politics by exploring the evolving role of downtown business elites in light of the Olympic experience of Atlanta and it represented an initial attempt to explore this phenomenon. While the results are not universally representative, they nonetheless provide insights to see the regime evolvement.

The mega-event literature suggests that megaevents have the potential to be the catalyst for host cities to apply their planning strategies in a more focused environment, and they can result in remarkable changes in infrastructure, urban form, and city image. Nevertheless, the economic value of the Olympics is not as important as it was before. The Olympics became more complex to plan and stage and it is unlikely for another city to be able to organize an Olympic Games without any government support. Even in Atlanta case, where no governmental support was "expected" by ACOG, the Games cost millions of dollars to governments and tax payers. Moreover, it is also hard to convince the residents that Olympics have huge promises to transform the host city. Atlanta's Olympic experience showed that expecting urban transformation as a result of the Games is not realistic without comprehensive planning effort as well as intention to create legacies. This means, the results of the Olympics depend on the strategies that are implemented and the planning efforts to achieve these strategies. The Olympic experience of Atlanta shows that the Games may have limited long-term impacts, if it was not intended to make significant changes.

Overall Atlanta Olympic experience suggests that the local policy settings matters the most for Summer Olympics planning. That is why we see different planning approaches and distinct legacies in different host cities. Even though the IOC has fixed strategies to handle the huge Olympic planning effort, the local settings of each host city results in different outcomes. In Atlanta, many of the infrastructures were already in place and the Olympics was a catalyst to speed up the process for some necessary improvements that needed to be made regardless of the Olympics. Olympics 
dramatically increased the image of Atlanta, which was the main goal for the business elites. Summer Olympics were one of those rare events that would put a city on the map quickly and the downtown Atlanta business elites wisely used this opportunity to create an international city image.

Regarding Atlanta's Olympic experience, the finding of this study is consistence with the previous literature in a sense that Atlanta Olympics created negative social impacts and did not improve the urban-living conditions for the residents. This study showed that Atlanta's Olympic strategy has produced results different than other Olympic host cities. Thus, the Atlanta Games are considered as a bad example of megaevent planning. However, Atlanta Olympics had no intention to create a legacy for its residents and transform the urban-living conditions. If we consider the initial strategy of Atlanta Olympic organizers, it was clear that the governing elites used the Olympics as a unique opportunity to accomplish their goals by overcoming the limitations of local government. The regime had its agenda with a set of purposes to accomplish. In conclusion, the local politics and context matter more than the fixed Olympic strategies. In other words, Olympics is not a "one-fits-all approach" for host cities, thus the outcomes differ from city to city mainly because of the different objectives, politics, and culture of each city.

Atlanta's Olympic experience also has some implications for planning practice. "Inside the fence" approach of Atlanta Olympic organizers showed that private planning initiatives are more likely to result in outcomes that are not necessarily consistent with the needs of the residents. Atlanta's Olympic planning practice mostly benefited the business interests while the desires and needs of the residents mostly disregarded, mainly because of the privately lead planning initiatives. The city transferred its decisionmaking power to profit-oriented private entities such as ACOG during the Olympic preparation process and as a result, the plans that are implemented mostly focused on meeting the needs of the business interests, not the residents. Public entities had limited money and/or support to implement major "outside the fence" development projects. Atlanta Olympic planning practice showed that privatization of the Olympic planning results in limited effects in urban transformation.

This study was able to provide evidence to the changing regime dynamics and the impact of
Olympic hosting on Atlanta's urban regime. However, the single-case study design limits the generalizability of this study's findings. The government structure in Atlanta is unique in a sense and cannot easily compared with other cities. The leadership of individuals, long-term relationships between elected officials, business leaders, different ethnic and race groups create a unique policy arena in Atlanta. Future research should focus on comparative cases to see the changing regime dynamics on different government settings. Atlanta's regime is still evolving and developing itself with revisions. As Stone (1976) stated, "revision is a constant process" in the instance of studies of local politics and public policy (p. 7). Therefore, this research offered one such revision to regime analysis and attempted to contribute to the body of urban policy and megaevent literature by providing additional insights on Olympic strategy of downtown Atlanta business elites.

\section{References}

ACOG Member 1. (2014) Personal interview, April 17.

Allen, I. with Hemphill, P. (1971) Mayor: Notes on the Sixties. New York: Simon and

Schuster

Andranovich, G., Burbank, M. J., and Heying, C. H. (2001) Olympic Cities: Lessons Learned from Mega-event Politics. Journal of Urban Affairs 23 (2), p. 113-131.

Atlanta Committee for the Olympic Games (ACOG). 1996. 1996 Olympic Press Guide. Retrieved from Atlanta History Center (Atlanta, USA).

Atlanta Committee for the Olympic Games (ACOG). (1997) Official Report of the Centennial Olympic Games, Volume One: Planning and Organizing.

Baade, R.A. and Matheson, V. (2002) Bidding for the Olympics: Fool's Gold? In Barros C; Ibrahimo M.; Szymanski , S. (Eds.), Transatlantic Sport: the Comparative Economics of North America and European Sports, p. 127-151.

Banfield, E. C. (1965) Big City Politics: A Comparative Guide to the Political Systems of Atlanta, Boston, Detroit, El Paso, Los Angeles, Miami, Philadelphia, St. Louis and Seattle. New York: Random House.

Burbank, M. J., Andranovich, G. and Heying, C. (2001) Olympic Dreams: The Impact of Megaevents on Local Politics, Lynne Rienner Publishers, Boulder, Colorado.

Burbank, M. J., Andranovich, G., and Heying, C. (2002) Mega-events, Urban Development, and Public Policy. The Review of Policy Research, Fall 2002 (19) 3: p. 179-202. 
Essex, S. and Chalkley B. (1998) The Olympics as a catalyst of urban renewal: a review. Leisure Studies, 17 (3), 187-206.

Essex, S. and Chalkley, B. (2003) Urban transformation from hosting the Olympic Games: university lecture on the Olympics [online article]. Barcelona: Centre d'Estudis Olímpics (UAB). International Chair in Olympism (IOC-UAB). http://olympicstudies.uab.es/lectures/web/pdf/ess ex.pdf. \[Date of consulted: 08/10/2014]

French, S. P. and Disher, M. E. (1997) Atlanta and the Olympics: A One-Year Retrospective. Journal of the American Planning Association, 63 (3) Summer, p. 379-392.

Heying, C., Burbank, M. J., and Andranovich, G. (2007) World Class: Using the Olympics to Shape and Brand the American Metropolis. Chapter 9 in Smith, Melanie K., Tourism, Culture, and Regeneration. CABI Publishing.

Hoffman, A. V. (2003). House by House, Block by Block: The Rebirth of America's Urban Neighborhoods. Oxford University Press.

Holmes, R. A. (1977). The Politics of Governmental Reforms in the Atlanta Metropolitan Region. In Gorsuch, E.N. and Hinds, D. S. 1977. The Future of Atlanta's Central City. Research Monograph No. 73, Georgia State University College of Business Administration.

Hutton, A. K. 2001. The Olympic Games: Lessons for Future Host Cities. Master Thesis Dalhousie University, Halifax, Nova Scotia.

International Olympic Committee (IOC) (1978) Agreement between IOC and the City of Los Angeles, (27 October), typescript.

International Olympic Committee (IOC) (1979) Agreement between IOC, United States Olympic Committee and Organizing Committee of Games (1 March), typescript.

International Olympic Committee (IOC).2009. Fact Sheet. Host City Election Facts and Figures.

Keating, L. 2001. Atlanta: Race, Class, and urban Expansion. Temple University Press, Philadelphia.

Murphy, A. D. (1997). Introduction: Atlanta: Capital Of The 21st Century? Urban Anthropology and Studies of Cultural Systems and World Economic Development, Vol. 26, No. 1, Atlanta: Capital of the 21st Century (Spring, 1997), pp. 1-8.

Payne, B. (1997). Lessons from Atlanta, The organizer's view: $Q \& A$ with Billy Payne. The Cincinnati Enquirer. Sunday, July 27, 1997.

Pound, R. W (1994) The Centennial Olympic Games, Atlanta, 1996. Vice President, International
Olympic Games. Delivered at the Ambassador's lecture series, Washington, D.C., May 16.

Preuss, H. (2004) The Economics of Staging the Olympics: A Comparison of the Games, 19722008. Edward Elgar Publishing.

Roche, M. (2002) Mega Events and Modernity. Olympics and Expos in the Growth of Global Culture. Routledge.

Rutheiser, C. (1996) How Atlanta lost the Olympics. New Statesman (1996). 125.4293 (July 19, 1996): p28. Cover story

Short, J. R. (2004) Global Metropolitan: Globalizing Cities in a Capitalist World. Routledge

Short, J. R. (2018) Hosting the Olympic Games: The Real Costs for Cities. Routledge

Stone, C. N. (1976) Economic Growth and Neighborhood Discontent: System Bias in The Urban Renewal Program of Atlanta. The University of North Carolina Press: Chapel Hill.

Weisman, S. (1990) Atlanta Selected Over Athens for 1996 Olympics. The New York Times. September, 19,1990

Zimbalist, A. (2011) Circling the Bases: Essays on the Challenges and Prospects of the Sports Industry. Temple University Press, Philadelphia. 